\title{
Biochemical and Morphological Studies of Rat Submandibular Gland: III. Effects of Testosterone Treatment on Proteins of Granule-Rich Fraction
}

\author{
C. T. Hanks and S. G. Chakrabarti* \\ Institute of Dental Research, Departments of Oral Pathology and Oral Histology, School of \\ Dentistry, University of Michigan, Ann Arbor, Michigan 48109, USA
}

Mature adult male rats and castrated and testosterone-treated castrated adult rats were injected with pilocarpine $\mathrm{HCl}$ and ${ }^{s}$-H-lysine and sacrificed sequentially over an eight-hour time period. Follozeing homogenization and differential cenirifugation, three subcellular fractions from each group of animals were analyzed by gel electrophoresis and liquid scintillation. Two proteins in the granule-rich fraction appeared in larger amounts on the densitometric scans and appeared to represent a larger proportion of newly synthesized proteins than the other proteins.

Rodent submandibular glands (SMGs) and their alkaline esteropeptidases (AEP) have been investigated since Lacassagne first described differences in male and female mouse SMGs in $1940 .{ }^{1}$ They are the source of numerous embryonic growth factors in mice. ${ }^{2,3}$ In addition, both mouse and rat SMGs are the source of enzymes with trypsin-like proteolytic activity capable of activating nerve growth factor (NGF) and epidermal growth factor (EGF) as well as inducing inflammatory changes. All of these biologic properties are probably due to arginine esterase activity. ${ }^{4-6}$ Early investigations described the parallel development of proteoly. tic activity in rat gland homogenates and the granulation of the convoluted tubules associated with the maturation of male rats. ${ }^{7,8}$ Later, biochemical studies suggested that the major AEP enzymes in rat and mouse submandibular glands are testosterone-dependent. ${ }^{9,10}$

In previous papers, our laboratory reported separation of cellular organelles from homogen-

This investigation was supported, in part, by $\mathrm{Na}$ tional Institutes of Health Research Grants DE-02731 and DE-02289 from the National Institute of Dental Research, Bethesda, Md.

Received for publication October 11, 1976.

Accepted for publication December 6, 1976.

* Present address: Division of Dermatology, Howard University Medical College, Washington, D.C. ates of rat SMG by differential centrifugation and the partial purification of a granule-rich fraction, about $85 \%$ of which consisted of dense. zymogen-like granules. ${ }^{11,12}$ This fraction contained between 40 and $60 \%$ of the total AEP activity of the gland. Chromatographic fractions containing protein as well as high AEP activity were resolved on polyacrylamide gel electrophoresis into a number of Coomassie Blue staining bands. The present study was undertaken to determine if testosterone treatment of castrated animals would alter the electrophoretic patterns or enhance the synthesis of certain proteins of the granular $\left(P_{2}\right)$ fraction over that observed in similar preparations from castrated or normal mature control animals. In addition, data ars presented for comparing the mitochondria-rich fraction and the final supernatant fraction to the granule-rich fraction.

\section{Materials and Methods}

In the first study, 24 male and 12 female Sprague-Dawley rats, 30 days old, were divided into groups of six animals each (Table 1). One group of six male rats and one group of six female rats were sacrificed immediately by exsanguination through the inferior vena cava under nembutal anesthesia. Two groups of six male rats each were castrated immediately. One week prior to sacrifice, each animal in one of these groups (CAST-TP) was subcutaneously given one injection of $5 \mathrm{mg}$ testosterone propionate (TP) in $1 \mathrm{ml}$ sesame oil. The other group (CAST) was otherwise untreated. Experimental and control animals were fed laboratory chow and water ad libitum and handled frequently by laboratory personnel. The remaining four groups were sacrificed in a similar manner as were the immature animals when the normal male animals (MATURE) weighed almost $400 \mathrm{gm}$. The SMGs were removed, cleaned of connective tissue, weighed while wet, 
TABLE 1

Protease and Esterase Activities in Combined Homogenates of Submandibular Glands

\begin{tabular}{|c|c|c|c|c|c|c|c|}
\hline & \multirow{2}{*}{$\begin{array}{c}\text { Age } \\
\text { (days) }\end{array}$} & \multirow{2}{*}{$\begin{array}{l}\text { Av. Body } \\
\text { Wt. (gms) }\end{array}$} & \multirow{2}{*}{$\begin{array}{l}\text { Av. } \\
\text { Single Gland } \\
\text { Wt. (gms) }\end{array}$} & \multicolumn{2}{|c|}{ BAPA* $^{*}$} & \multicolumn{2}{|c|}{ BAEE $\dagger$} \\
\hline & & & & $\mathrm{pH} 8$ & $\overline{\mathrm{pH} 9.2}$ & $\mathrm{pH} 8$ & $\mathrm{pH} 9.2$ \\
\hline Immature Male (6) & 30 & 76 & 0.125 & n.m. & n.m. & 9.28 & 8.91 \\
\hline Immature Female $(6)$ & 30 & 79 & 0.125 & n.m. & n.m. & 7.64 & 9.48 \\
\hline Mature Male (6) & 87 & $392 \pm 2.4$ & 0.342 & 0.203 & 0.208 & 58.5 & 91.3 \\
\hline Mature Female (6) & 85 & $304 \pm 2.5$ & 0.25 & 0.194 & $-\S$ & 56.9 & 62.9 \\
\hline Cast (6) & 81 & $344 \pm 4.1$ & 0.31 & 0.09 & 0.09 & 35.4 & 47.6 \\
\hline Cast-TP (6) \# & 86 & $355 \pm 8.1$ & 0.25 & 0.106 & 0.108 & 42.8 & 46.5 \\
\hline
\end{tabular}

* $\alpha$-N-benzoyl arginine p-nitroanilide; sp. act. ( $\mu$ moles hydrolyzed $/ \mathrm{mg}$ prot/min) at $37 \mathrm{C}, 410 \mathrm{~nm}$.

$\dagger \alpha$-N-benzoyl arginine ethyl ester; sp. act. ( $\mu$ moles hydrolyzed $/ \mathrm{mg} \mathrm{prot} / \mathrm{min}$ ) at $25 \mathrm{C}, 253 \mathrm{~nm}$.

\$ Not measurable.

$\S$ Sample lost.

\# One subcutaneous injection of testosterone propionate $(5 \mathrm{mg})$, one week before sacrifice.

and minced. Homogenization of pooled groups of glands and centrifugal fractionation was carried out as described in a previous paper. ${ }^{11}$

In the second study, in order to determine the effects of multiple doses of TP, 18 male Sprague-Dawley rats, one month old, were separated into three groups (Table 2). Again, two groups were castrated immediately. The third group served as normal mature control animals. One of the castrated groups (CAST) was otherwise untreated. The second castrated group (CAST-TP) received subcutaneous injections of $1 \mathrm{mg} \mathrm{TP}$ in $1 \mathrm{ml}$ sesame oil every other day from the day of castration until sacrificed (26 treatments). In order to synchronize new protein synthesis, all three groups of animals were injected with freshly prepared pilocarpine $\mathrm{HCl}$ ( $160 \mathrm{mg} / \mathrm{kg}$ body weight) on the day of sacrifice. Fifteen minutes later, ${ }^{3} \mathrm{H}$-lysine $(1 \mu \mathrm{Ci} / \mathrm{gm}$ body weight) was injected intraperitoneally into each animal. Pairs of animals from each group were then sacrificed at 30 minutes, 3 hours, and 8 hours following pilocarpine administration. The glands from animals at each time period were pooled, homogenized, and centrifuged as described previously. ${ }^{11}$ Peptidase and estcrase activities, wherever reported, were measured using the trypsin substrates $\mathrm{N}$-benzoylDL-arginine-p-nitroanilide (BAPA) and Nbenzoyl-L-arginine ethyl ester-hydrochloride (BAEE), respectively, as described previously. ${ }^{11}$ Protein concentration was determined by Lowry's method. ${ }^{13}$

* Gilford 2400 Spectrophotometer, Gilford Instrument Laboratories, Inc., Oberlin, Oh.

+ New England Nuclear, Boston, Ma.

\$ Packard Tri-Carb Mode1 3320 Liquid Scintillation, Spectrometer, Packard Instrument Co., Inc., Downers Grove, Il.
ANALYSIS OF CENTRIFUgal FRACTIONS.Subcellular fractions $P_{2}$ (granule-rich fraction), $\mathrm{P}_{3}$ (mitochondria-rich fraction), and $\mathrm{S}_{4}$ (final supernatant fraction) were freeze-thawed six times to fracture membranes and solubilize proteins. Aliquots of each fraction containing between 100 and $350 \mu \mathrm{gm}$ protein were subjected to polyacrylamide gel electrophoresis using an anionic system as described previously. ${ }^{12}$ The samples were run in duplicate and simultaneously on gels of the same length. Current was applied until the tracking dye was near the end of the gels. Following electrophoresis, each gel was sliced longitudinally. Half the gel was stained with $0.5 \%$ amido black in $7 \%$ acetic acid and scanned at $650 \mathrm{~nm}$ on a recording spectrophotometer.* The second half of the gel was prepared for liquid scintillation by sectioning it transversely in $2 \mathrm{~mm}$ slices, each of which was squashed and incubated with $1 \mathrm{ml}$ of $30 \%$ $\mathrm{H}_{2} \mathrm{O}_{2}$ at $50 \mathrm{C}$ until digested (approximately two hours). The scintillation mixture consisted of this sample plus $10 \mathrm{ml}$ Aquasol. $f$ The counts were made on duplicate gels at $4 \mathrm{C}$ in a liquid scintillation spectrometer.t.

The protein content of each amido blackstained band was estimated by the intensity of staining as judged by the densitometric scan. A kodalithic photocopy of a sheet of uniform dots, $1.5 \mathrm{~mm}$ in diameter and $5 \mathrm{~mm}$ apart was placed over each densitometric scan. The total number of dots under the total scan area was considered $100 \%$ and proportional to the total amount of protein placed on the gel. The amount of protein in any slice or under any peak was proportional to its part of the total scan.

The radioisotope incorporation into the 
TABLE 2

Esterase Actrvities in Combined Homogenates of Submandibular Gland

\begin{tabular}{|c|c|c|c|c|c|}
\hline & \multirow[b]{2}{*}{$\underset{\text { (days) }}{\mathrm{Agg}}$} & \multirow[b]{2}{*}{$\begin{array}{l}\text { Av. Body } \\
\text { Wt. (gms) }\end{array}$} & \multirow{2}{*}{$\begin{array}{c}\text { Av. } \\
\text { Single Gland } \\
\text { Wt. (gms) }\end{array}$} & \multicolumn{2}{|c|}{ BAEE* } \\
\hline & & & & $\mathrm{pH} 8$ & pH 9.2 \\
\hline Mature Male (6) & 80 & $348 \pm 5.9$ & 0.25 & & \\
\hline $30 \mathrm{~min}$ & & & & 33.0 & 51.2 \\
\hline $3 \mathrm{hr}$ & & & & 48.8 & 47.2 \\
\hline $8 \mathrm{hr}$ & & & & -1 & +52.8 \\
\hline Cast-Male (6) & 84 & $415 \pm 8.8$ & 0.24 & & \\
\hline $30 \mathrm{~min}$ & & & & 21.2 & 25.3 \\
\hline $3 \mathrm{hr}$ & & & & 22.3 & 22.1 \\
\hline $8 \mathrm{hr}$. & & & & 24.7 & 34.6 \\
\hline Cast-TP-Male $(6) \ddagger$ & 84 & $384 \pm 5.9$ & 0.34 & & \\
\hline $30 \mathrm{~min}$ & & & & 53.5 & 59.6 \\
\hline $3 \mathrm{hr}$ & & & & 55.8 & 76.8 \\
\hline $8 \mathrm{hr}$ & & & & 81.1 & 123.0 \\
\hline
\end{tabular}

* $\alpha$-N-benzoyl arginine ethyl ester; sp. act. ( $\mu$ moles hydrolyzed $/ \mathrm{mg}$ prot $/ \mathrm{min}$ ) at $25 \mathrm{C}, 253 \mathrm{~nm}$.

$\dagger$ Sample lost.

$¥$ All animals given 26 treatments, each of $1 \mathrm{mg}$ testosterone propionate.

proteins was estimated by the counts per minute (cpm) in each $2 \mathrm{~mm}$ slice. The total $\mathrm{cpm}$ in all 20 slices was roughly equivalent to the radioactivity in the gel as determined by the quantity of protein placed on the gel. At the same time, the $2 \mathrm{~mm}$ slices served as a good reference to measure position of protein bands in the densitometric scans.

\section{Results}

The first and second studies were carried out in order to determine if there were dramatic differences in the effects of a single, but rather large, dose of TP and multiple doses of smaller amounts of TP. Further, the first study established a baseline for AEP activity to which our experimental and control values from the second study could be compared. Many of the differences in body weight and gland weight between the animals in the two studies may be accounted for by long-term testosterone deficiency (CAST and CAST-TP groups in the first study) and by the stressful effects of pilocarpine $\mathrm{HCl}$ in the second study.

Protease (BAPA hydrolysis) and esterase (BAEE hydrolysis) specific activities at two different $\mathrm{pH}$ values are shown for the combined SMG homogenates of each group of six animals in the first study in Table 1. Although the protease activity in 30-day-old animals was too low to be measured, the esterase activity ranged from 10 to $16 \%$ of that found in the adult normal controls. The esterase activities of the castrated males were 50 to $60 \%$ of those in the normal controls. The same activity in castrated animals treated one week prior to sacrifice with

TABLE 3

Distribution of Esterase Agtivity* in SMG Fragtions of CAST and

CAST-TP Animals at Timed Intervals After Pilocarpine HCl Treatmen't

\begin{tabular}{lcccccc}
\hline & \multicolumn{3}{c}{ CAST-TP } & & \multicolumn{3}{c}{ CAST } \\
& $30 \mathrm{~min}$ & $3 \mathrm{hr}$ & $8 \mathrm{hr}$ & $30 \mathrm{~min}$ & $3 \mathrm{hr}$ & $8 \mathrm{hr}$ \\
\hline Comb H & 59.6 & 76.8 & 123 & 25.3 & 22.1 & 34.6 \\
$\mathrm{fNP}$ & 20.1 & 34.2 & 34.4 & 13.0 & 18.6 & 22.7 \\
$\mathrm{P}_{2}$ & 123 & 161 & 167 & 31.0 & 54.9 & 78.9 \\
$\mathrm{P}_{3}$ & 31.3 & 29.9 & 19.6 & 5.58 & 9.05 & 9.1 \\
$\mathrm{P}_{4}$ & 5.53 & 17.8 & 17.5 & 1.58 & 4.9 & 4.54 \\
$\mathrm{~S}_{4}$ & - & 58.3 & 77.4 & 12.0 & 18.1 & 20.2 \\
\hline
\end{tabular}

* $\mu$ moles BAEE hydrolyzed/mg prot/min at $25 \mathrm{C}, \mathrm{pH} 9.2$. 
TP was not remarkably higher than the untreated castrated animals.

In the second study, in which multiple doses of TP were given to one group, there was a large increase in spectific esterase activity, most notably at three and eight hours after pilocarpine HCl treatment (Table 2). The glands were considered to be functioning normally at the eight-hour interval. At eight hours, the specific esterase activity of the combined homogenates of the CAST-TP group was more than twice that of the MATURE control group and nearly four times that of the CAST group. Additionally, in each group there was a gradual recovery of activity over the eight-hour period following pilocarpine treatment.

Table 3 demonstrates that, for both the CAST-TP and CAST groups of animals from the second study, the $\mathbf{P}_{2}$ fraction had the highest BAEE hydrolysis activity at all time intervals. Therefore, the $\mathrm{P}_{2}$ fractions received the most attention in the electrophoretic analysis. The
$\mathrm{S}_{4}$ fractions were also analyzed because they had high activity. The $\mathrm{P}_{3}$ fractions were analyzed as a check on our system and because they might contain some contaminating granular proteins.

The three centrifugal fractions taken from all animals sacrificed at three and eight hours after pilocarpine were analyzed electrophoretically. Figure 1 shows the electrophoretic patterns for six samples: the $\mathrm{P}_{2}, \mathrm{P}_{3}$ and $\mathrm{S}_{4}$ fractions of the CAST-TF and the CAST groups sacrificed at eight hours after pilocarpine treatment. These patterns were drawn while visualizing the gels by indirect fluorescent lighting. Although these gels were intact, they were marked by a razor blade when the remaining half of the gel was being sectioned transversely for liquid scintillation analysis. Consequently, the bands are designated by the slice number(s) in which they occurred. A few bands were found in several of these gels. Particular attention was paid to bands associated with slices 3 ,
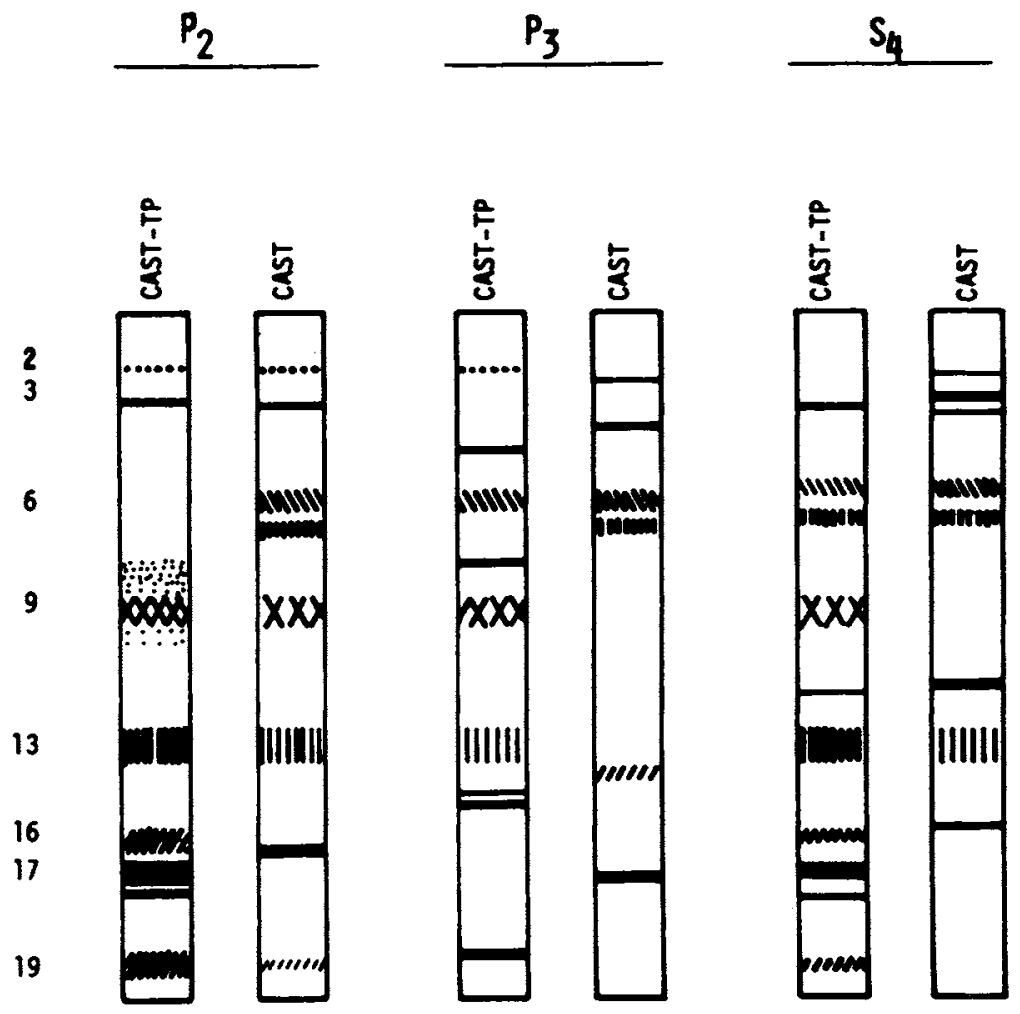

Fig 1.-Diagrammatic representation for gel patterns of $P_{2}, P_{3}$ and $S_{4}$ centrifugal fractions from CAST-TP and CAST groups of animals sacrificed eight hours following pilocarpine $\mathrm{HCl}$ treatment. Gel slice number is marked to the left of the diagram. Gel origin is at the top and anode is at the bottom of the figure. 


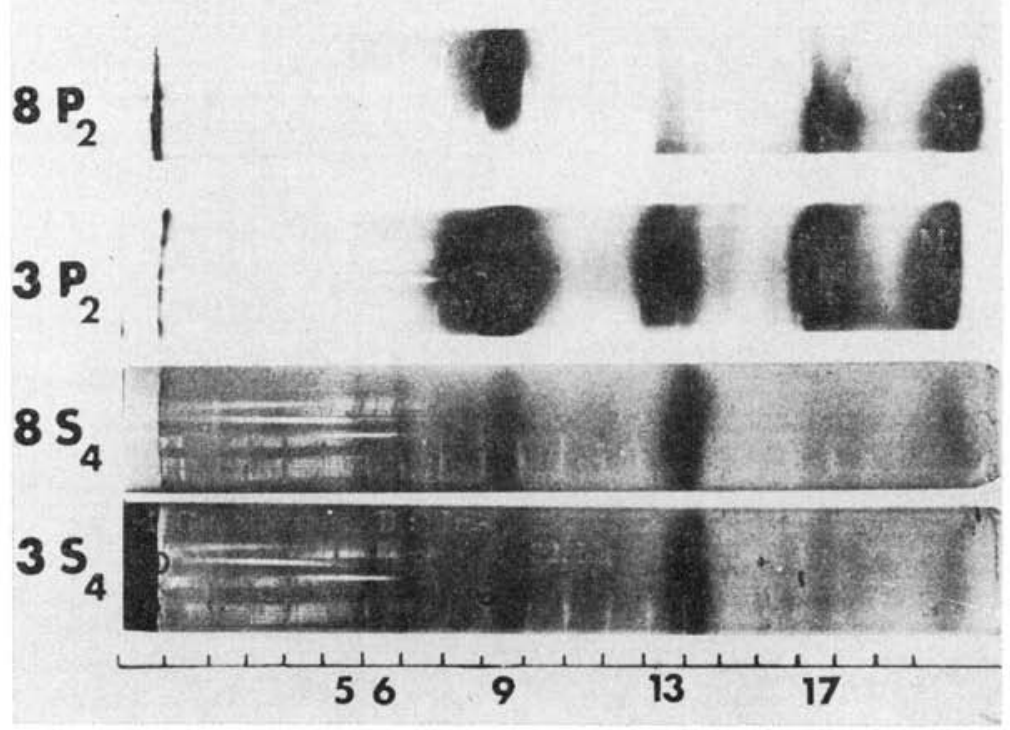

Fig 2.-Electrophoretic gel patterns of $\mathrm{P}_{2}$ and $\mathrm{S}_{4}$ fractions from CASTTP animals. Gels were run simultaneously and were made from samples taken at three and eight hours after pilocarpine $\mathrm{HCl}$ treatment. Gels were stained with amido black. Gel slices are numbered on lower margin. Anode is at the right margin.

TABLE 4

Proportion of Total Protein in Each Gel Slice

\begin{tabular}{|c|c|c|c|c|c|c|c|}
\hline & \multicolumn{7}{|c|}{ Gel Slice No. } \\
\hline & 5 & 6 & 9 & 13 & 16 & 17 & 19 \\
\hline \multicolumn{8}{|l|}{$\mathrm{P}_{2}$ Gels } \\
\hline \multicolumn{8}{|l|}{ Mature } \\
\hline $8 \mathrm{hr}$. & _* & $\begin{array}{r}0 \\
29\end{array}$ & 10 & 21 & $\begin{array}{l}3 \\
9\end{array}$ & $\begin{array}{l}7 \\
8\end{array}$ & $\begin{array}{l}1 \\
1\end{array}$ \\
\hline \multicolumn{8}{|l|}{ Cast } \\
\hline $3 \mathrm{hr}$. & 6 & 6 & 9 & 27 & - & - & - \\
\hline $8 \mathrm{hr}$. & 7 & 7 & 7 & 6 & 1 & 1 & - \\
\hline \multicolumn{8}{|l|}{ Cast-TP } \\
\hline $3 \mathrm{hr}$. & - & 2 & 50 & 14 & 11 & 6 & 16 \\
\hline $8 \mathrm{hr}$. & 2 & 2 & 36 & 13 & 11 & 8 & 10 \\
\hline \multicolumn{8}{|l|}{$\mathrm{S}_{4}$ Gels } \\
\hline \multicolumn{8}{|l|}{ Mature } \\
\hline $3 \mathrm{hr}$. & - & - & - & - & - & - & - \\
\hline $8 \mathrm{hr}$. & 6 & 2 & - & 3 & - & - & - \\
\hline \multicolumn{8}{|l|}{ Cast } \\
\hline $3 \mathrm{hr}$. & 12 & 8 & - & 15 & - & - & - \\
\hline $8 \mathrm{hr}$. & 13 & 9 & - & 13 & - & - & - \\
\hline \multicolumn{8}{|l|}{ Cast-TP } \\
\hline $3 \mathrm{hr}$. & 9 & 9 & 16 & 16 & 2 & 3 & 3 \\
\hline $8 \mathrm{hr}$. & 7 & 6 & 18 & 13 & 6 & 4 & 2 \\
\hline
\end{tabular}

* Indicates O.D. on densitometric scan was extremely low or negligible. 
$5-6,9,13,16-17$, and 19, all of which were observed to some extent in the $\mathrm{P}_{2}$ gels. Most of them were present in the $\mathrm{P}_{2}$ gels of the CAST group, but to a lesser degree than in the CASTTP group.

Figure 2, which compares the three- and eight-hour $\mathrm{P}_{2}$ samples from the CAST-TP group, shows the distinct patterns common to $\mathrm{P}_{2}$ samples and those common to the $\mathrm{S}_{4}$ samples, although some of the minor bands from Fig 1 are not obvious. The $\mathrm{P}_{2}$ samples from the CAST-TP group had strong bands associated with slices $8-9,16-17$, and 19 and weaker bands at 5-6 and 13 . Conversely, the $\mathrm{P}_{2}$ samples from both the CAST group and the MATURE control group, as well as all $S_{4}$ fractions, had the heaviest banding at slices 5-6 and
13, with much weaker bands in the 8-9, 16-17, and 19 slice areas. Visually, the most unique change in the $\mathrm{P}_{2}$ samples from the CAST-TP group was an intense amido black stain in the 8-9 area, which appeared to "spill" over into the $\mathrm{S}_{4}$ samples from the same group. This is interpreted as a major $P_{2}$ protein which contaminated the supernatant fraction because of breakage of secretory granules during homogenization.

The relative proportions of protein in the $\mathrm{P}_{2}$ and $\mathrm{S}_{4}$ fractions from each group are compared in Table 4. This method standardizes the densitometric scans so that they may be compared even if the same amount of protein was not placed on each gel. Thirty-six to $50 \%$ of the protein on the $\mathrm{P}_{2}$ gels of the CAST-TP

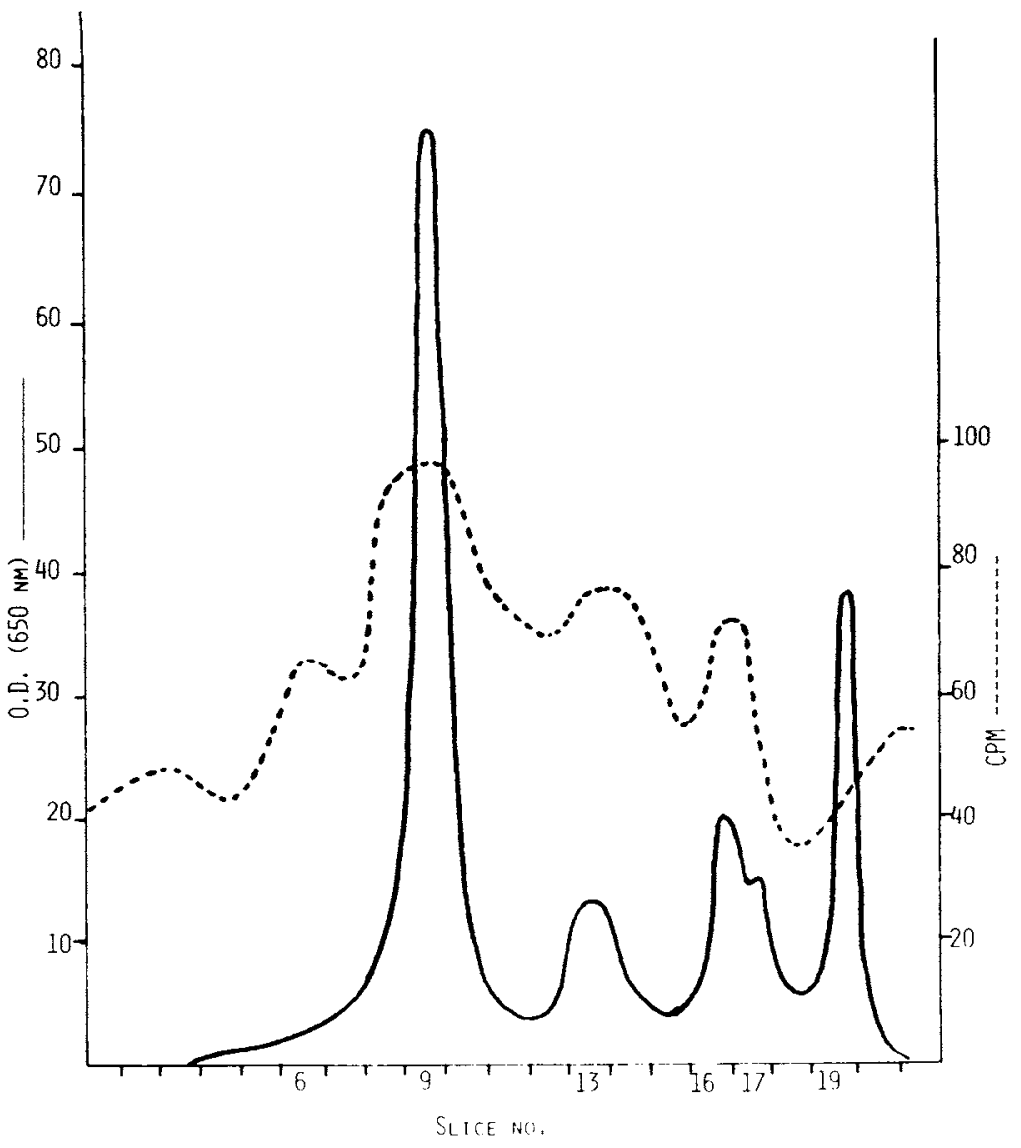

FIG 3.-Electrophoretic gel analysis of granule-rich $\left(\mathrm{P}_{2}\right)$ fraction from animals treated with multiple doses of $1 \mathrm{mg} / \mathrm{kg}$ body weight testosterone propionate following castration. Adult animals were sacrificed eight hours following pilocarpine $\mathrm{HCl}$ treatment. Solid line, densitometric scan of amido black stained gel; broken line, radioactivity as ${ }^{3} \mathrm{H}$-lysine in gel slices. Positive pole and direction of movement of proteins is to right. 


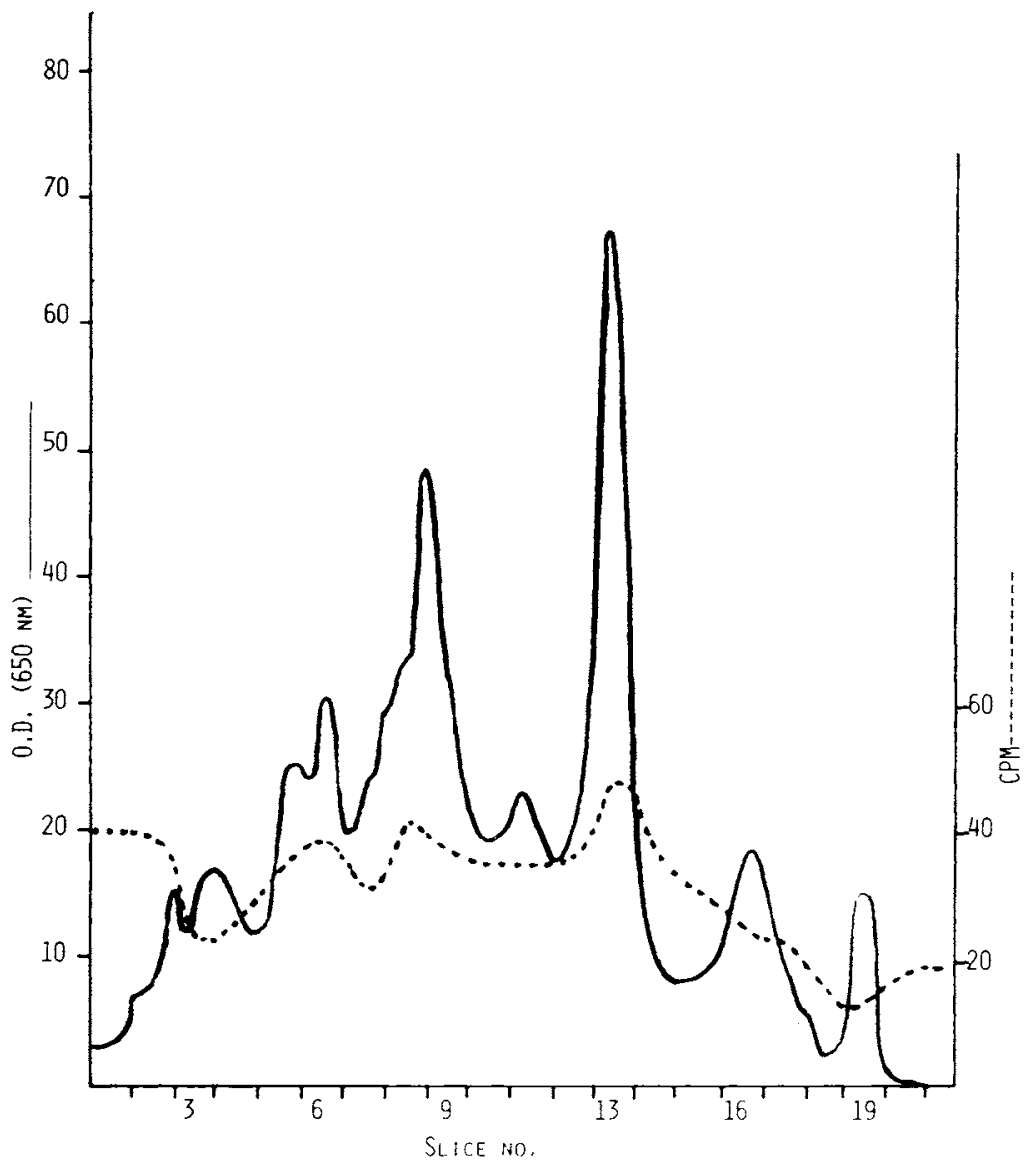

FIG 4.--Electrophoretic gel analysis of soluble proteins from final supernatant $\left(\mathbf{S}_{4}\right)$ fraction from animals treated with multiple doses of $1 \mathrm{mg} / \mathrm{kg}$ body weight testosterone propionate following castration. Adult animals were sacrificed eight hours following pilocarpine HCI treatment. Solid line, densitometric scan of amido black stained gel; broken line, radioactivity as ${ }^{3} \mathrm{H}$-lysine in gel slices. Positive pole and direction of movement of proteins is to right.

group were associated with slice 9 . Also, a relatively large proportion of the protein of most of the $\mathrm{S}_{4}$ gels and the $\mathrm{P}_{2}$ gels of the CAST group and the MATURE control group was associated with slice 13 .

Densitometric scans at $650 \mathrm{~nm}$ of material staining with amido black and corresponding radioactivity levels were made for each gel. Two representative scans are presented in Figs 3 and 4 , of eight-hour $\mathrm{P}_{2}$ and $\mathrm{S}_{4}$ samples from the CAST-TP animal group, respectively. The dramatic difference between the levels of protein in slices 9 and 13 are obvious from these scans.

In order to quantitate what proportion of newly synthesized protein these peaks repre- sented, gel slices which fell under peaks of radicactivity in these two scans (Figs 3 and 4) were grouped. Thus, group I consisted of slices 4-6; group II, 7-11; group III, 12-14; group IV, 15-18; and group $V, 19-20$. The relative proportions of radioactivity incorporated into these slices from $\mathrm{P}_{2}$ gels are presented in Table 5 . These data represent the proportions of new prctein synthesized in a three-hour period and in an eight-hour period following pilocarpine treatment, and are not necessarily comparable to the total protein in Table 4 . The proportions of radioactivity in the MATURE group were considered to represent normal new protein synthesis during recovery. Focusing specifically on the group II slices, the percentages of radioac- 
TABLE 5

Proportion of Radioactivity in Various Groups of Gee Sliges

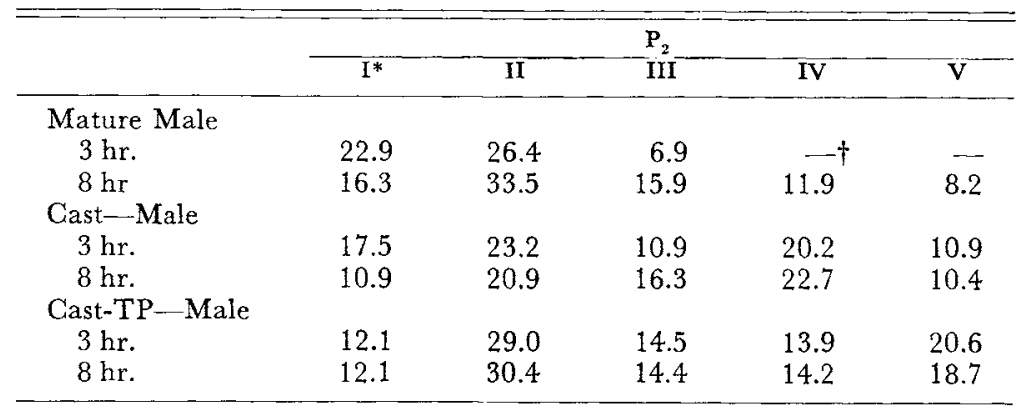

* Groups of gel slices: $\mathrm{I}=$ slices $4-6 ; \mathrm{II}=7-11 ; \mathrm{III}=12-14 ; \mathrm{IV}=15-18 ; \mathrm{V}=19-20$.

† Samples Iost.

tivity in the $\mathrm{P}_{2}$ samples of the CAST animals were much lower than in the MATURE controls, while in the CAST-TP animals they were almost the same. Furthermore, the CAST-TP group V gel slices had a much greater percentage of radioactivity in them than did the same slices from the CAST and MATURE animals. This suggests that multiple doses of $1 \mathrm{mg} \mathrm{TP}$ probably enhanced the synthesis of those group II and group V proteins over that of castrated animals without hormone replacement. The percentage of incorporation of radioactivity in group III gel slices of the $\mathrm{S}_{4}$ samples was also about the same for all animals. Although the data are not presented here, radioactivity in the Group III gel slice of this $\mathrm{S}_{4}$ sample was also about the same for all groups of animals (15-20\%).

\section{Discussion}

The parasympathomimetic drug, pilocarpine $\mathrm{HCl}$, was selected to synchronize protein synthesis and perhaps enhance the visualization of TP-dependent protein. Cutler and Chaudhry ${ }^{14}$ described morphologic extrusion of secretory granules from convoluted granular tubule (CGT) cells of rat SMG at 15 minutes following injection of pilocarpine $\mathrm{HCl}(160 \mathrm{mg} / \mathrm{kg}$ body weight). There appeared to be complete morphologic recovery of these cells within eight hours following treatment. Using starvation and refeeding as a synchronizing method for protein synthesis, Matthews ${ }^{15}$ also demonstrated by autoradiography peaks of radioactivity in apical proteins in CGT at four hours and at 12 hours after a "pulse" injection of tritiated tryptophan. This may represent different rates of synthesis and secretion of two secretory proteins or protein groups by the CGT. In the present study, AEP activity gradually increased over the eight-hour recovery period following pilocarpine treatment in MATURE control animals, in castrated animals, and in testosterone-treated castrated animals (Table 2). The effect was most dramatic for the CAST-TP group. Furthermore, at least one protein (slice 9) and perhaps a second (slice 19) appeared to be stimulated by testosterone treatment to a greater extent than other SMG granular proteins (Tables 4 and 5 ).

A recent paper by Ekfors et al. ${ }^{16}$ presented electrophoretic densitometry scans of soluble proteins from adult female and young male rat SMGs following homogenization. The scan of adult rat, although female, bears some resemblance to the $\mathrm{S}_{4}$ scans from the CAST-TP group in this paper (Fig 4). In another figure from the paper of Ekfors et al. ${ }^{16}$ there were scans of soluble proteins from homogenized SMG of 11 day-old untreated rats and 11-day-old rats treated five days with isoproterenol (IPN). The scan from the 11-day-old rat lacked all the spiked peaks of our Fig 4, but did have a broad low rise in optical density in the region of slices 2-13. IPN treatment for five days was associated with a new spike in the region of our slices 5-6. This strongly suggests to us that slices 5-6 contain an acinar cell secretory protein. Hence, it also could be epected to some extent in our $\mathrm{P}_{2}$ fractions. Also, it was not surprising to find this protein in our $\mathrm{S}_{\mathbf{4}}$ fractions, since existing evidence indicates that all granular proteins are synthesized by the endoplasmic reticulum. The densitometric scan of adult female SMG soluble proteins from the paper of Ekfors et al. ${ }^{16}$ also indicated to us that the proteins peaking in the five areas of gel slices 2-3, 
5-6, 8-9, 13, and 16-17 may not be exclusive to male rats.

Other evidence suggested that the protein in gel slice 9 or gel slice 19 may be the alkaline esteropeptidase, glandulain, described by Riekkinen et al. ${ }^{9}$ They found, from their enzymatic studies, that multiple injections of TP stimulated the increased synthesis of this enzyme in castrated adult male rats, normal adult male rats, and normal adult female rats. That it is possible to further stimulate an already existent system for synthesizing a particular protein by increasing circulating serum testosterone was also in agreement with the data from female and young mice SMG. ${ }^{10}$ Barrett and Bell ${ }^{17}$ demonstrated three peaks of alkaline protease activity, using benzoyl-arginine- $\beta$-naphthylamide (BANA) at $\mathrm{pH} 9.5$ in homogenates of adult rat SMG. These authors also suggested that the major protease, active at $\mathrm{pH} 9.2$ and with an $R f$ value of 0.8 , was the same protein $(s)$ which was missing from the newborn SMG scan in the vicinity of the anode in the paper by Ekfors et al. ${ }^{16}$ Thus it would seem that the proteins missing in the newborn rat SMG homogenate would also include the protein in gel slices 1617 and 19 of the present study. The meaning of this finding is not clear. It supports the evidence that the slice 19 protein might be a CGT granular protein developing after puberty. The slice 15-16 proteins may simply appear at a later time in granular development, but evidence as to their testosterone dependency is not strong.

\section{Conclusions}

The data in this paper lend further support that the rat $\mathrm{SMG}$ s are testosterone-sensitive organs. There is evidence for cytosol binding sites for dihydrotestosterone in mice ${ }^{18}$ and rats, ${ }^{19}$ but not for testosterone. ${ }^{19}$ However, unlike mice $\mathrm{SMG}$, rat SMG metabolizes testosterone to steroids of less androgenic potency. ${ }^{20}$ The problem now scems to be the relationship between androgen binding to cytosol and nuclear reccptors and androgen metabolism by systems which are present in classical androgendependent tissues as well as other androgensensitive tissues. ${ }^{21-22}$ To what extent is the binding and metabolism of various androgens by one or more systems necessary for morphological and functional expression in rodent SMGs?

Data in this paper support previous evidence of stimulation of systems synthesizing one or several granular proteins which are sensitive to testosterone, ${ }^{9}$ although other factors may also be involved in their development. ${ }^{23}$ Testosterone-stinulated alkaline esteropeptidases have been shown to be closely bound to NGF and $\mathrm{EGF}$ in mouse SMG, and to effect the activation of these growth factors by proteolytic cleavage. ${ }^{4-5}$ Perhaps a similar type of cleavage by the rat enzymes are responsible for activating salivary kallikrein, renin, and other as yet undescribed factors associated with rat SMG.

We would like to thank Mrs. Shirley P. Johnson and Dr. Mary Ann Calcott for their technical assistance with this work, and Dr. Ellen O. Smith and Mrs. Helen Kassem for their editing and help in preparing the manuscript.

\section{References}

1. LaGassagne, A.: Dimorphisme Sexual de la Glande Sous-Maxillaire á l'Hormone Male, Chez la et le Rat, $C R$ Soc Biol (Paris) 133:180, 1940.

2. Levi-Montalcini, R, and Angeletti, P.U.: Nerve Growth Factor, Physiol Rev 48:534, 1968.

3. Cohen, S.: Isolation of a Mouse Submaxillary Gland Protein Accelerating Incisor Eruption and Eyelid Opening in the Newborn Animal, J Biol Chem 237:1555, 1962.

4. TAYlor, J.M.; Mitchell, W.M.; and CoHEN, S.: Characterization of the Binding Protein for Epidermal Growth Factor, J Biol Chem 249:2188, 1974.

5. Moore, J.B.; Mobley, W.C.; and Shooter, E.M.: Proteolytic Modification of the $\beta$ Nerve Growth Factor Protein, Biochem 13 (4) : 833, 1974 .

6. ERDös, E.G.; TAgUe, L.L.; and Miwa, I.: Kallikrein in Granules of the Submaxillary Gland, Biochem Pharmacol 17:667, 1968.

7. SREEBNY, L.M.: Studies of Salivary Gland Proteases, Ann NY Acad Sci 85:182, 1960.

8. Shafer, W.G., and Muriler, J.C.: Endocrine Influences Upon the Salivary Glands, Ann NY Acad Sci 85:215, 1960.

9. Riekrinen, P.J., and Niemi, M.: AndrogenDependent Salivary Gland Protease in the Rat, Endocrinol 83 (6): 1224, 1968.

10. Angeletti, R.A.; Angeletti, P.U.; and Calissano, P.: Testosterone Induction of Estero-Proteolytic Activity in the Mouse Submaxillary Gland, Biochim Biophys Acta $139: 372,1967$.

11. Hanks, C.T., and Chakrabartr, S.G.: Biochemical and Morphological Studies of Rat Submandibular Gland: I. Centrifugal Fractionation of Granule-Rich Fraction, J Dent Res 54(5):938, 1975.

12. Chakrabarti, S.G.; Hanks, C.T.; and Johnson, S.P.: Biochemical and Morphological Studies of Rat Submandibular Gland: II. Partial Purification of Proteins from Granule-Rich Fraction, $J$ Dent Res $54(5): 948,1975$. 
13. Lowry, O.H.; Rosenbrough, N.J.; Fatr, A.L.; and Randall, R.J.: Protein Measurement with the Folin Phenol Reagent, J Biol Chem 193:265, 1951.

14. Cutler, L.S., and Chaudhry, A.P.: Release and Restoration of the Secretory Granules in the Convoluted Granular Tubules of the Rat Submandibular Gland, Anat Rec $176(4): 405,1973$.

15. Matthews, R.W.: Measurement of Protein Synthesis in the Rat Submandibular Gland Using Tritiated Tryptophane, Arch Oral Biol 19:985, 1974.

16. Ekfors, T.; Chang, W.W.L.; Bressler, R.S.; and BARKA, T.: Isoproterenol Accelerates the Postnatal Differentiation of Rat Submandibular Gland, Dev Biol 29:38, 1972.

17. Barrett, M.L., and Ball, W.D.: Development of the Rat Salivary Glands: II. The Identification of a Trypsinlike Protease in the Submaxillary Gland, Dev Biol 36:195, 1974.
18. Wilson, J.D., and Goldstein, J.L.: Evidence for Increased Cytoplasmic Androgen Binding in Submandibular Gland of Mouse with Testicular Feminization, $J$ Biol Chem $247: 7342,1972$.

19. Charreau, E.H., and Baldi, A.: AndrogenProtein Interactions in Rodent Submaxillary Glands, Acta Physiol Lat Amer 21:37, 1971.

20. Baldi, A. and Charreau, E.H.: Testosterone Metabolism by Rodent Submaxillary Glands in Relation to their Sexual Dimorphism, Acta Physiol Lat Amer 22:11, 1972.

21. Goffey, J.C.: Steroid Metabolism by Mouse Submaxillary Glands: I. In Vitro Metabolism of Testosterone and 4-Androstene-3, 17dione, Steroids 22:247, 1973.

22. Massa, R., and Martini, L.: Testosterone Metabolism: A Necessary Step for Activity? J Ster Biochem 5:941, 1974.

23. Dunn, J.F., and WILson, J.D.: Developmental Study of Androgen Responsiveness in the Submandibular Gland of the Mouse, Endocrinol 96(6): 1571, 1975. 